\title{
Pembangunan Sistem Informasi Pemberian Kredit Pada Koperasi Mekarsari Dengan Metode Rapid Application Development
}

\author{
Nur Hidayati ${ }^{1}$, Ety Nurhayaty ${ }^{2}$ \\ ${ }^{1}$ Program Studi Sistem Informasi, Universitas Bina Sarana Informatika \\ e-mail: nur.nrh@bsi.ac.id
}

${ }^{2}$ Program Studi Sistem Informasi Akuntansi, Universitas Bina Sarana Informatika e-mail: ety.eyy@bsi.ac.id

Cara Sitasi: Hidayati, N., \& Nurhayaty, E. (2019). Pembangunan Sistem Informasi Pemberian Kredit Pada Koperasi Mekarsari Dengan Metode Rapid Application Development. Paradigma - Jurnal Komputer dan Informatika, 21(2), 205-214. doi:10.31294/p.v21i2.6279

\begin{abstract}
The cooperative is a business entity that is very well known by pro people, because the cooperative is group of individuals who run its business based on family principle, Pancasila and the Undang-Undang 1945. The cooperatives development in Indonesia indicates a positive trend and known by the public. One of them is Cooperative Mekarsari. This filled Mekarsari cooperative is getting better every day. Cooperative Mekarsari provided many services to members, one of them is about the granting of credit or loans. Granting of credit given is usually devoted to the retirement, although not close the possibility of members who are not retired can ask loan. However, data processing in granting credit Cooperative Mekarsari is still done manually, giving rise to some problems, such as the granting of credit or loans still recorded using handwritten into the book loans, still merge the recording of data between loan and installment, there is no limitation work space that allows the data become no secret. By looking at it, then this requires the existence of a Cooperative system to facilitate development in the processing of the data and provide services to its members. And to assist in the process of developing such a system, it is necessary to use an appropriate method, i.e. the Rapid Application Development method. The expected results of this form system development, program application is expected to resolve the existing problems in Cooperative Mekarsari.
\end{abstract}

Keywords: program application, cooperation, $R A D$, loan

\section{PENDAHULUAN}

Pasal 33 Undang-Undang Dasar 1945 ayat satu berbunyi perekonomian disusun sebagai usaha bersama berdasarkan atas azas kekeluargaan (Fuad, 2016). Koperasi merupakan salah satu pilar utama yang membantu roda perekonomian di Indonesia khususnya bagi kalangan masyarakat menengah kebawah. Koperasi merupakan kumpulan orang yang secara sukarela ingin mengikutsertakan dirinya untuk mensejahterakan anggota dengan berlandaskan asas kekeluargaan. Koperasi di Indonesia sekarang ini berkembang dengan pesat. Badan Pusat Statistik menyampaikan bahwa jumlah Koperasi di wilayah Jawa Barat khususnya mencapai 16.855 unit. Sedangkan Kementrian Koperasi dan Usaha Kecil Menengah mengatakan bahwa jumlah Koperasi sampai bulan Desember 2015 sebanyak 212.135 unit.

Berdasarkan jumlah Koperasi tersebut, maka Koperasi terbagi menjadi dua, yaitu 61.912 unit tidak aktif dan 150.223 unit Koperasi aktif. Dan dari empat tahun terakhir, mulai dari tahun 2012,
2013, 2014, dan 2015 dapat diketahui bahwa ratarata jumlah Koperasi aktif sebanyak 4139 unit (Tofik Isa \& Hartawan, 2017). Dengan melihat perkembangan Koperasi tersebut, tentunya dalam Koperasi membutuhkan adanya sistem informasi yang baik, sehingga memberikan kemudahan dalam mengelola data-data yang ada dalam Koperasi.

Menurut Indrajani, sistem dapat diartikan sebagai sekelompok elemen-elemen yang saling berinteraksi atau berhubungan satu sama lainnya untuk mencapai maksud dan tujuan bersama, dengan menerima input, mengolahnya dan menghasilkan output (Anggoro, Umar, Vinanty, \& Dananjaya, 2015). Dan sebagai sarana penunjang untuk menghasilkan output yang lebih baik, maka digunakanlah komputer. Komputer yang dilengkapi dengan aplikasi program tertentu tentunya akan membantu dalam penggunaan sistem informasi dalam Koperasi. Namun belum semua Koperasi yang ada sudah menerapkan sistem informasi yang baik, seperti pada Koperasi Mekarsari. 
Paradigma - Jurnal Informatika dan Komputer, 2September2019

P-ISSN 1410-5063, E-ISSN: 2579-3500

Koperasi Merkasari merupakan Koperasi Simpan Pinjam, sehingga sering disebut dengan nama KSP Mekarsari. Koperasi ini berdiri mulai dari tahun 2000 di daerah Cileungsi Bogor. Koperasi Mekarsari memberikan layanan pemberian kredit atau pinjaman khususnya kepada para pensiun yang dikeluarkan oleh Taspen dan Asabri, dimana pembayaran uang pensiunnya dapat melalui Bank BRI, Bank BTPN ataupun melalui Kantor Pos sebagai mitranya. Pemotongan uang pensiun dan penyaluran kredit merupakan salah satu bentuk kerjasama yang diberikan. Kredit dapat diartikan sebagai kegiatan usaha bank dalam menyediakan uang ataupun melakukan tagihan yang dilandasi dengan adanya kepercayaan antara pihak yang memberi pinjaman dengan pihak yang menerima pinjaman berdasarkan perjanjian yang telah dibuat (Setiawan \& Rinawati, 2015). Definisi kredit atau pinjaman tersebut haruslah dipahami oleh setiap anggota yang ada dalam Koperasi.

Pada saat Koperasi akan memberikan kredit atau pinjaman kepada anggota, tentunya Koperasi akan melakukan pengecekan terlebih dahulu, untuk dapat menyimpulkan apakah anggota layak mendapat pinjaman atau tidak, hal ini dilakukan supaya ke depannya pembayaran kreditnya berjalan dengan lancar sehingga tidak terjadi kredit macet yang dapat mengganggu operasional Koperasi (Syafriansyah, 2015). Koperasi Mekarsari dalam pengelolaan pemberian kredit kepada para anggota masih dilakukan secara manual. Sehingga, hal ini menimbulkan beberapa permasalahan, seperti : pemberian kredit kepada para anggota masih dicatat dalam buku pinjaman dengan tulisan tangan, hal ini mengakibatkan pelayanan kepada anggota menjadi lambat dan terdapat kesulitan untuk melakukan update data; pencatatan transaksi pemberian kreditnya ke dalam buku pinjaman dan angsuran anggota menjadi satu sehingga petugas Koperasi harus membolak balikkan dokumen tersebut untuk mengetahui besar pinjaman yang diberikan; penyimpanan dokumennya kurang rapi sehingga menyebabkan dokumen tercecer dan hilang, hal ini akan berakibat kurang menyenangkan bagi anggota dan dalam pembuatan laporannya pun menjadi tidak akurat; serta belum ada pembatasan ruang kerja, yang dapat mengakibatkan keamanan dan kerahasiaan dokumen milik nasabah menjadi kurang terjamin serta dapat terjadinya manipulasi terhadap datanya.

Dengan adanya permasalahan diatas, maka Koperasi Mekarsari sangat membutuhkan adanya pengembangan sistem terutama dalam sistem pemberian kredit kepada para anggotanya. Pengembangan sistem tentunya memerlukan waktu yang tidak sebentar, karena memerlukan adanya pemahaman apa yang diperlukan dalam sistem tersebut. Sehingga untuk melakukan pengembangan sistem ini memerlukan adanya penggunaan metode yang tepat supaya apa yang menjadi tujuan dalam pengembangan sistemnya tercapai. Metode Rapid Application Development $(R A D)$ dapat digunakan untuk membantu dalam menyelesaikan permasalahannya. Ada beberapa tahapan dalam metode $R A D$, dan dengan mengikuti tahapan dalam metode ini maka hasil yang diperoleh dalam membangun atau mengembangkan sistem dapat tercapai secara maksimal. Untuk membantu dalam menggambarkan sistem beserta pengembangan sistemnya, maka diperlukan tools yang bernama UML (Unified Modelling Language).

Karena UML merupakan salah satu metodologi berorientasi objek yang saat ini paling sering digunakan diseluruh dunia (Nugroho, 2017). UML dapat diartikan sebagai bahasa pemodelan untuk perangkat lunak ataupun sistem yang mempunyai paradigma berbasis objek. Modelling atau pemodelan tersebut nantinya dapat digunakan untuk membuat permasalahan yang rumit menjadi sederhana sehingga mudah dipahami dan dipelajari (Nugroho, 2017).

Menggabungkan teknik-teknik pemodelan berorientasi objek menjadi standarisasi merupakan tujuan dari UML. Pada diagram UML 2.3 terdiri dari 13 diagram yang dikelompokkan menjadi 3 kategori, yaitu structure diagrams, behavior diagrams dan interaction diagrams (Sukamto \& Shalahuddin, 2018). Dalam pembahasan jurnal ini, ada empat macam diagram yang digunakan untuk membantu menggambarkan sistemnya, yaitu activity diagram, use case diagram, class diagram, dan sequence diagram.

Diagram Use Case dikembangkan langsung dari dokumen SRS (Software Requirements Specification). Pada dasarnya, Aktor berada di luar sistem ataupun di luar perangkat lunak yang secara langsung berinteraksi dengan sistem atau perangkat lunak yang sedang dikembangkan. Use case diagram pada dasarnya digunakan untuk menggambarkan mengenai kesatuan luar yang akan menggunakan sistem atau perangkat lunak. Kesatuan luar aatau eksternal entity ini sering disebut dengan aktor. Sedangkan deskripsi diagram use case ini lebih menekankan pada sistem dari sudut pandang penggunanya dan juga menekankan pada interaksi yang terjadi diantara pengguna dengan sistem (Nugroho, 2017).

Biasanya sequence diagram menggambarkan tingkah laku dari satu scenario tunggal. Diagram sequence menunjukkan objek-objek yang terlibat dalam proses tersebut dan bagaimana urutan penyampaian pesanpesan antar objek. Sequence diagram biasanya dilampirkan pada satu use case untuk menjelaskan eksekusi use case tersebut. Sebuah sequence diagram menggambarkan interaksi dalam bentuk grafik dua dimensi, yaitu dimensi vertical dan dimensi 
horizontal. Dimensi vertical merupakan waktu yang dimulai dari atas ke bawah, sedangkan dimensi horizontal menunjukkan peranan yang dimainkan objek-objek tunggal dalam kolaborasi (Akil, 2018).

Dalam membangun ataupun mengembangkan sistem, maka diperlukan struktur sistem secara jelas, hal ini dapat dibuatkan dalam Class Diagram, yang didalamnya berisi mengenai class-class yang dibutuhkan (Sugiarti, 2018). Kelas (Class) menggambarkan suatu konsep diskret terhadap aplikasi yang dimodelkan. Kelas merupakan himpunan dari objek-objek yang memiliki strukturstruktur yang serupa, serta memiliki perilaku dan relasi yang serupa pula (Nugroho, 2017).

\section{METODOLOGI PENELITIAN}

Dalam melakukan penelitian terhadap pembangunan atau pengembangan sistem informasi pemberian kredit pada Koperasi Mekarsari ini, penulis menggunakan penelitian kualitatif, dimana data-data yang diperoleh berasal dari hasil observasi, wawancara maupun studi pustaka. Pembangunan atau pengembangan sistem tersebut adalah menyusun sistem yang baru untuk menggantikan sistem yang sudah ada atau cukup dengan memodifikasinya pada bagian-bagian tertentu (Tohari, 2014). Pengembangan sistem ini dilakukan, karena beberapa hal, seperti : adanya permasalahan dalam sistem yang lama; untuk meraih kesempatan karena teknologi informasi berkembang dengan pesat serta adanya perintah yang berasal dari Pimpinan ataupun pihakpihak yang berkaitan dengan organisasi.

Berikut adalah langkah-langkah yang dilakukan dalam penelitian ini :

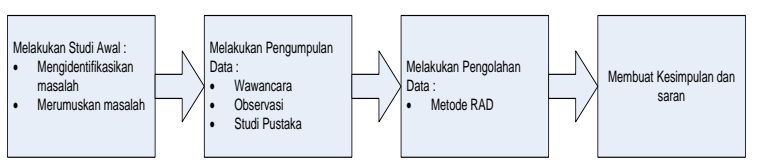

Gambar 1. Langkah-langkah Penelitian

Keterangan:

1. Melakukan Studi awal

Dalam tahap melakukan studi awal ini, penulis terlebih dahulu mempelajari sistem yang berjalan pada Koperasi Mekarsari terutama mengenai sistem pemberian kredit kepada para Anggota. Selanjutnya mengidentifikasikan masalah dan merumuskan permasalahan yang dihadapi dalam Koperasi tersebut.

\section{Melakukan Pengumpulan Data}

Kegiatan melalukan pengumpulan data ini dapat dilakukan dengan beberapa cara. Adapun cara tersebut adalah melalui wawancara, observasi dan studi pustaka. Wawancara merupakan proses untuk memperoleh keterangan dari narasumber dengan cara bertatap muka secara langsung dan menggunakan panduan wawancara yang telah dipersiapkan sebelumnya. Observasi merupakan kegiatan yang melakukan pengamatan secara langsung terhadap objek yang diteliti. Sedangkan studi pustaka artinya menelusuri literatur, dimana literature tersebut dapat digunakan untuk membantu dalam pembahasan studi kasus (Nazir, 2014).

3. Melakukan Pengolahan Data

Metode Rapid Application Development (RAD) merupakan salah satu metode dalam SDLC (System Development Life Cycle) yang digunakan untuk membantu dalam mengembangkan ataupun membangun sistem atau perangkat lunak yang bersifat incremental, dimana pembangunan sistem tersebut membutuhkan waktu yang tidak terlalu lama. Metode RAD ini merupakan adaptasi dari metode waterfall, dimana dalam RAD ini dilakukan pengembangan di setiap komponennya (Sukamto \& Shalahuddin, 2018). Berikut adalah gambar metode $R A D$ :

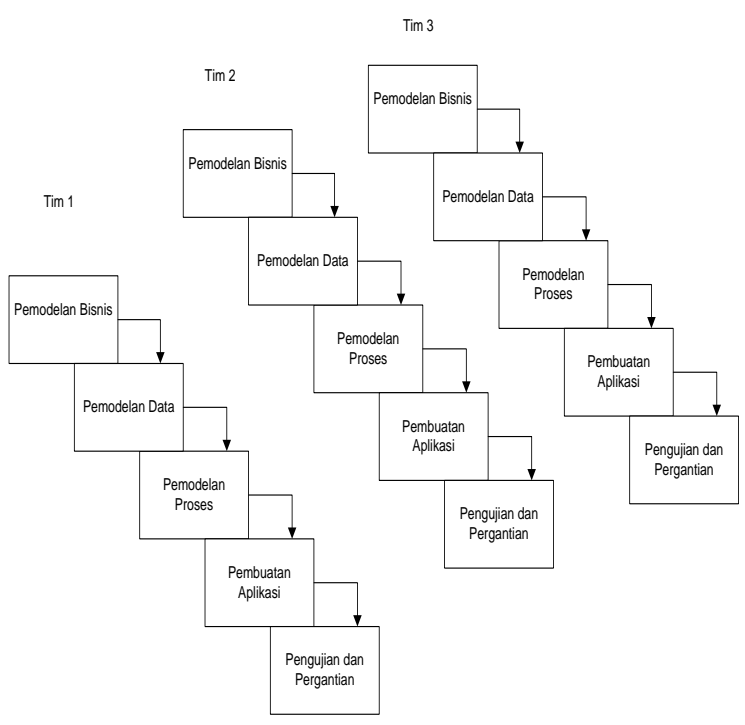

Sumber : (Sukamto \& Shalahuddin, 2018) Gambar 2 Metode $R A D$

Dari gambar RAD diatas terlihat adanya beberapa tim pengembang sistem. Jika kebutuhan dalam pembangunan sistem atau perangkat lunaknya sudah dipahami dengan baik serta adanya pembatasan dalam ruang lingkupnya, maka tim pengembang tersebut dapat menyelesaikan tugasnya untuk membangun sistem atau perangkat lunak secara cepat.

Berikut adalah penjelasan dari gambar RAD :

a. Pemodelan Bisnis

Dalam tahap pemodelan bisnis ini, setidaknya sudah bisa mendefinisikan mengenai fungsional sistemnya, seperti bagaimana proses bisnisnya, prosedur apa saja yang terkait dalam informasi yang akan disajikan, siapa yang akan membuat 
informasinya dan informasi apa saja yang akan dibuat.

b. Pemodelan Data

Setelah tahap pemodelan bisnis diselesaikan, maka tahap pemodelan data dilakukan. Dalam tahap ini mulai menentukan data-data apa saja yang dibutuhkan dengan mendefinisikan atribut atau field-fieldnya serta menentukan relasinya.

c. Pemodelan Proses

Dalam pemodelan proses ini, dilakukan pengimplementasian pemodelan bisnis yang berhubungan dengan pemodelan datanya.

d. Pemodelan Aplikasi

Yang dilakukan dalam pemodelan aplikasi ini adalah, mulai dibuatkan programnya dengan berdasarkan pemodelan proses dan pemodelan datanya.

e. Pengujian dan Pergantian

Melakukan pengujian terhadap program yang sudah dibuat sebelumnya ditahap pemodelan aplikasi dengan menggunakan data-data yang ada dalam suatu organisasi. Jika penujian tersebut berhasil, maka dapat beralih ke pengembangan komponen selanjutnya. Pengujian tersebut dilakukan supaya sistem yang baru pada saat diterapkan, sudah tidak ada kendala atau permasalahan yang dijumpai dalam sistem tersebut.

4. Membuat Kesimpulan dan Saran

Kesimpulan serta saran perlu dibuat untuk mengetahui gambaran secara jelas dari kondisi sistem yang ada dan pengembangan sistemnya.

\section{HASIL DAN PEMBAHASAN}

Proses bisnis yang sedang berjalan dalam sistem informasi pemberian kredit atau pinjaman pada Koperasi Mekarsari, dapat dijelaskan sebagai berikut :

a. Pengajuan Kredit

Pada proses pengajuan kredit ini, Anggota terlebih dahulu melakukan pengajuan kredit ke Bagian Kredit Koperasi. Kemudian Bagian Kredit akan memberikan formulir permohonan pinjaman kepada Anggota untuk diisi. Setelah formulir permohonan pinjaman diisi oleh Anggota, maka Anggota mengembalikan formulir tersebut beserta syarat pengajuan kredit seperti fotocopy KTP, fotocopy Kartu Keluarga, Karip, Struk Gaji dan Jaminan pinjaman kepada Bagian Kredit untuk dilakukan proses pengecekan.

b. Persetujuan Kredit

Pada saat pengecekan terhadap berkas dokumen yang diberikan dari Anggota ke Bagian Kredit, dan Bagian Kredit mengatakan sudah lengkap maka Bagian Kredit akan membuatkan Surat Perjanjian Kredit (SPK). Jika dokumen belum lengkap, maka Bagian Kredit akan memberikan konfirmasi kepada Anggota.Selanjutnya berkas dokumen pinjaman dan SPK diserahkan kepada Pimpinan untuk dilakukan pemeriksaan ulang dan meminta persetujuan dari Pimpinan. Setelah Pimpinan menyetujui pengajuan kredit yang diusulkan Anggota, maka dokumen pinjaman beserta SPK dikembalikan ke Bagian Kredit.

c. Pencairan Dana

Setelah Pimpinan menyetujui pengajuan kredit dari Anggota, maka pencairan dana dapat dilakukan. Pada saat pencairan dana, Anggota akan memperoleh dana yang dipinjam beserta fotocopy SPK.

d. Pembuatan Laporan

Pada proses pembuatan laporan ini, dilakukan oleh Bagian Kredit, dimana setelah proses pengajuan kredit sampai pencairan dana selesai dilakukan. Laporan pemberian kredit ini akan diberikan kepada Pimpinan, sebagai informasi Anggota-anggota yang telah mendapatkan dana sesuai dengan yang diajukan. 


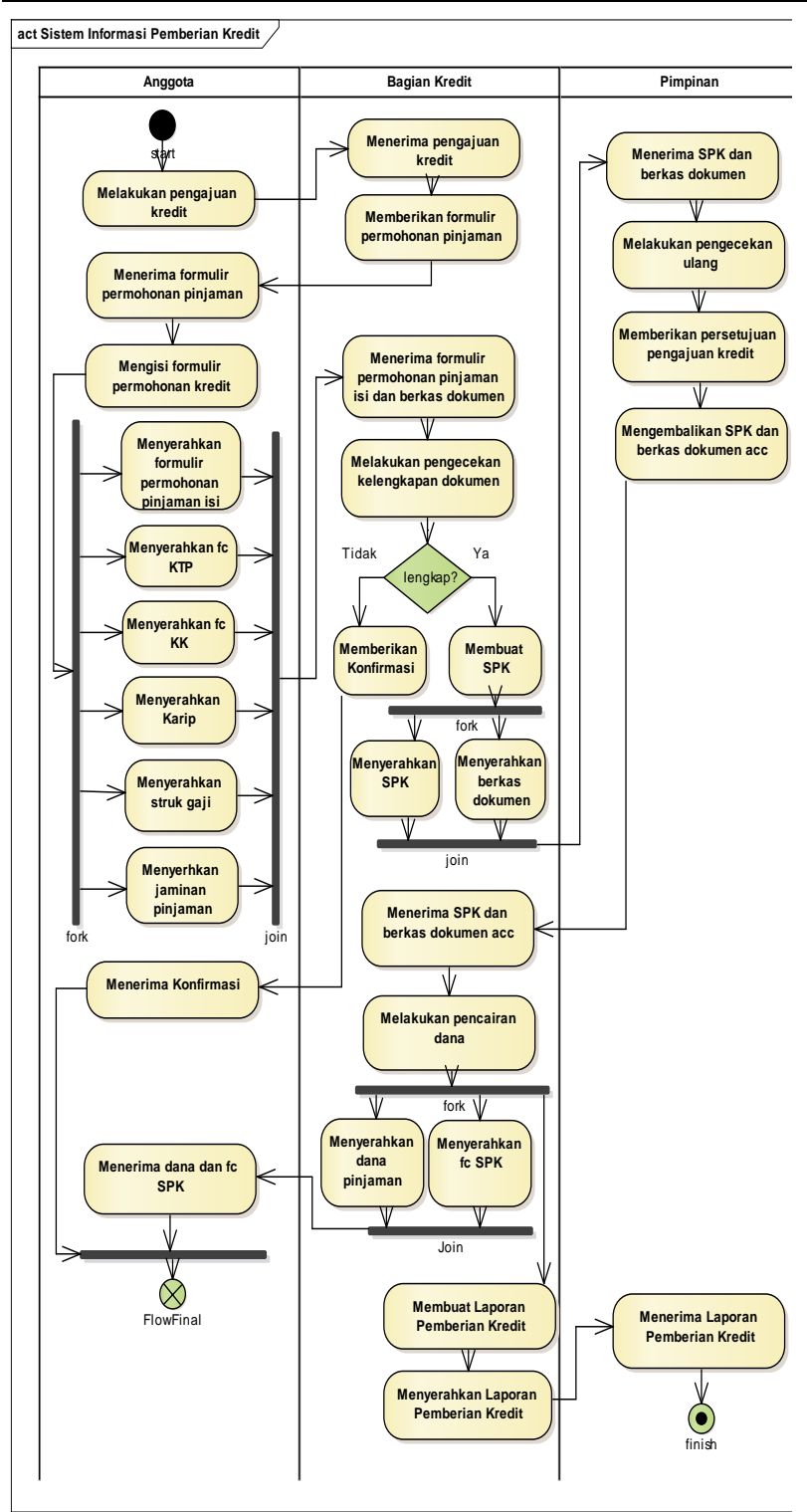

Gambar 3 Activity Diagram Sistem Berjalan Berikut adalah pembahasan dalam penggunaan metode RAD :

\section{Pemodelan Bisnis}

Setelah mengetahui bagaimana alur kerja dari sistem pemberian kredit pada Koperasi Mekarsari diatas (seperti yang digambarkan dalam activity diagram), maka langkah selanjutnya adalah menentukan kebutuhankebutuhan dari sistem atau perangkat lunak yang akan dibangun, sehingga nantinya dapat dibuatkan fungsionalitas sistem barunya. Untuk membuat hal tersebut, perlu adanya analisa kebutuhan. Menurut Press dalam Siahaan, analisa kebutuhan merupakan bagian dari proses pengembangan sistem yang memiliki peran untuk dapat menjembatani perbedaan pendapat yang sering terjadi antara level perancangan perangkat lunak dengan rekayasa kebutuhan (Hidayati, 2018). Menurut Wiegers dalam Siahaan, tujuan dari analisa kebutuhan ini adalah untuk melengkapi kebutuhankebutuhan yang ada serta untuk memastikan yang berkepentingan memahaminya serta dapat menemukan kekurangan atau kesalahan lainnya (Hidayati, 2018). Berdasarkan definisi dari analisa kebutuhan dan tujuan analisa kebutuhan itu sendiri, maka perlu sekali adanya komunikasi secara intens antara pemakai sistem dengan pengembang sistem untuk menentukan kebutuhan-kebutuhan yang diperlukan dalam pengembangan sistem informasi pemberian kredit pada Koperasi Mekarsari. Dan dengan melihat proses bisnis yang telah dijelaskan diatas beserta penggambaran sistem berjalannya dengan activity diagram, setidaknya memberikan gambaran mengenai sistem informasi pemberian kreditnya. Sehingga hal ini dapat dianalisa dan kemudian dapat ditentukan kebutuhan sistemnya. Berikut ini adalah penggambaran dari siapa yang menggunakan informasi tersebut dan apa saja yang dapat dilakukannya :

a. Bagian Kredit dapat melakukan login

b. Bagian Kredit mengelola data anggota

c. Bagian Kredit mengelola data user

d. Bagian Kredit mengelola pengajuan kredit

e. Bagian Kredit mengelola penerimaan kredit

f. Bagian Kredit mengelola pencairan dana

g. Bagian Kredit dapat mengakses laporan pemberian kredit

h. Pimpinan dapat melakukan login

i. Pimpinan dapat mengakses laporan pemberian kredit

Berdasarkan hasil penentuan fungsionalitas sistem penerimaan kredit diatas, maka dapat dibuatkan Use Case Diagram sebagai berikut : 


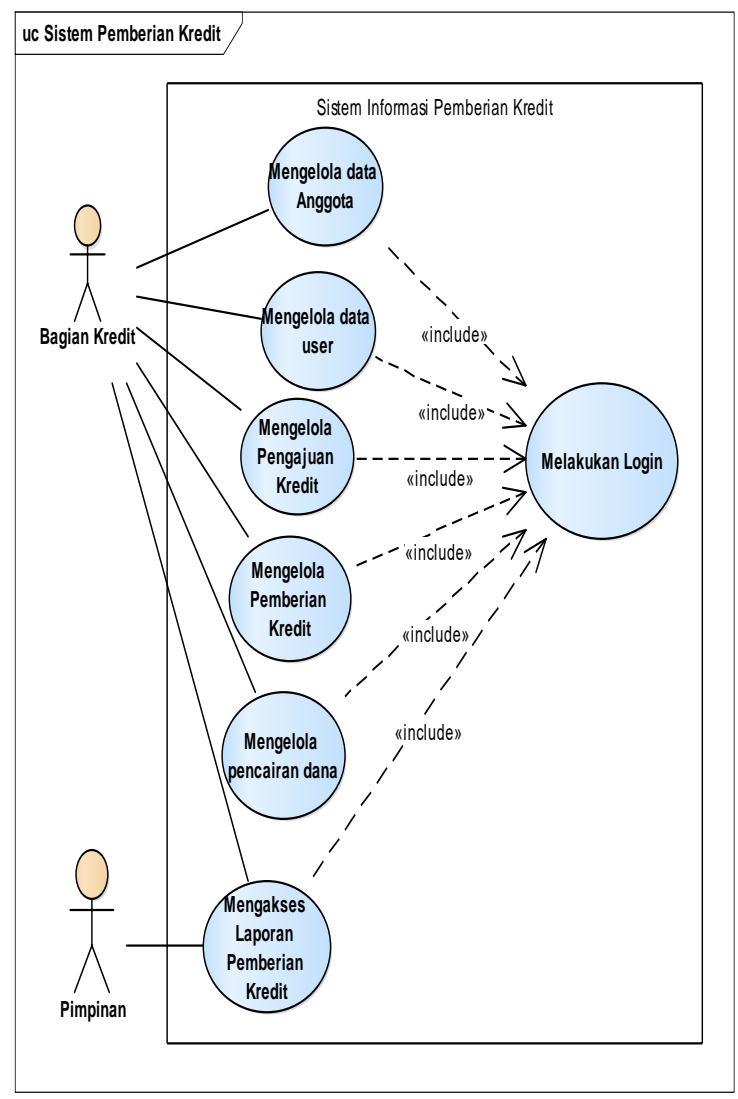

Gambar 4 Use Case Diagram Fish Level

\section{Pemodelan Data}

Dalam melakukan pemodelan data ini, penulis menggunakan class diagram untuk menggambarkan atribut-atribut yang digunakan beserta bagaimana relasinya. Kelas merupakan cetak biru atau blueprint yang mendefinisikan atribut-atribut dan perilaku-perilaku objek saat objek-objek ini diciptakan atau diintansiasi dari kelas-kelas yang bersangkutan (Nugroho, 2017). Class menggambarkan keadaan (atribut/properti) suatu sistem, sekaligus

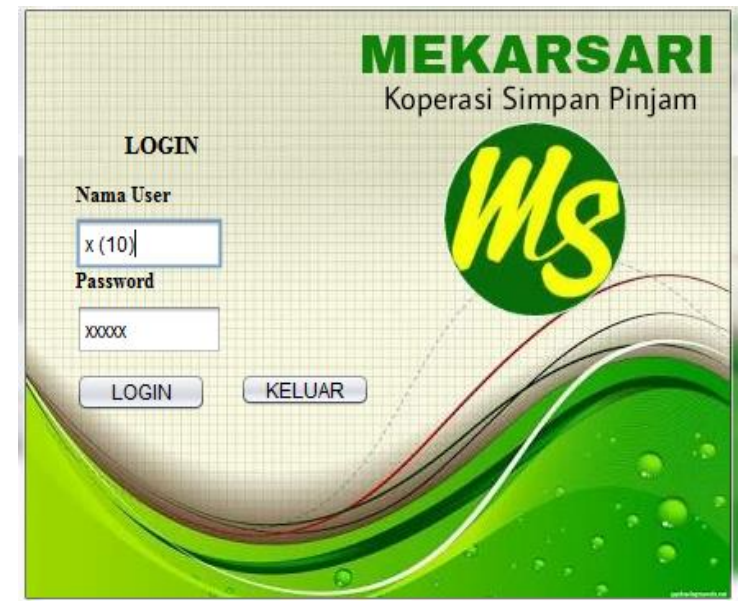

memberikan layanan untuk memanipulasi keadaaan tersebut (metode/fungsi), disampaikan oleh (Tohari, 2014). Class diagram dapat didefinisikan sebagai superset ERD (Entity
Relationship Diagram), alat pemodelan yang umum untuk perancangan konsep logis database. Dimana ERD hanya memfokuskan pada data, sedangkan class diagram selangkah lebih maju dengan menspesifikasikan data berikut tingkah lakunya (Akil, 2018). Berikut ini adalah penggambaran class diagram untuk sistem informasi pemberian kredit pada Koperasi Mekarsari :

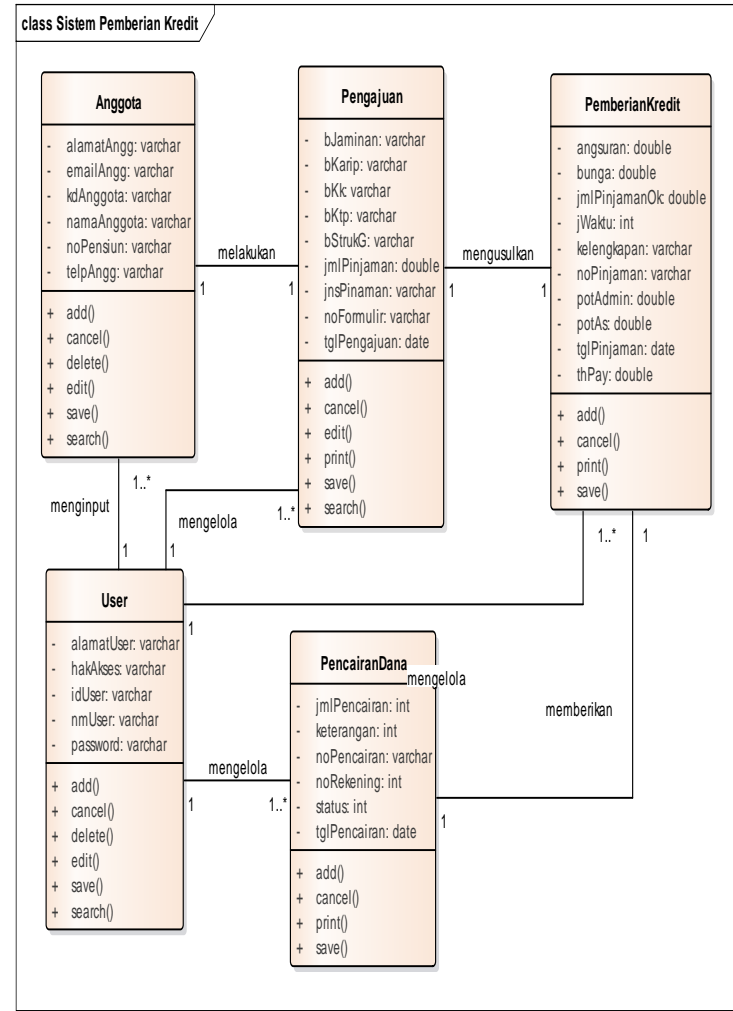

Gambar 5 Class Diagram

\section{Pemodelan Proses dan Pemodelan Aplikasi}

Pada tahap pemodelan proses dan aplikasi ini, dapat dijadikan satu karena masih berkelanjutan, dimana pemodelan proses meerupakan implentasi dari pemodelan bisnis dan data. Kemudian ke tahapan pemodelan aplikasi untuk dibuatkan aplikasi programnya. Sebelum dibuatkan aplikasi programnya, tentunya terlebih dahulu dibuatkan user interfacenya seperti yang dibutuhkan oleh usernya. Berikut ini adalah beberapa tampilan user interface yang digunakan dalam pembangunan sistem informasi pemberian kredit pada Koperasi Mekarsari :

Gambar 6 User Interface Login 


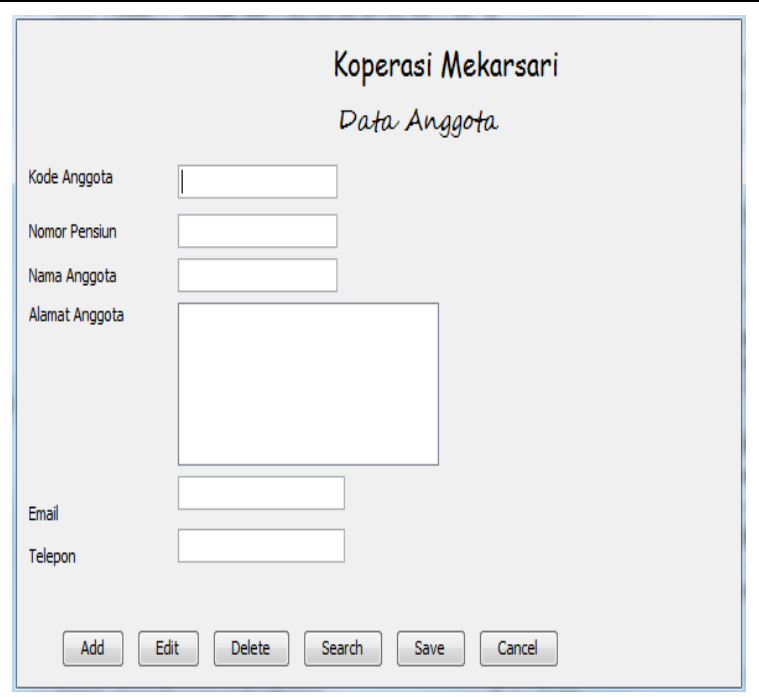

Gambar 7 User Interface Data Anggota

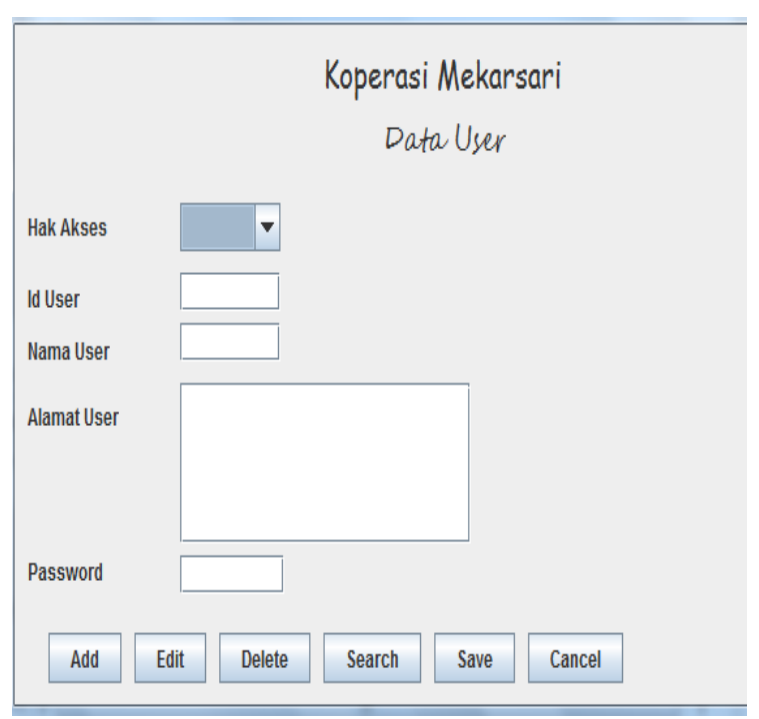

Gambar 8 User Interface Data User

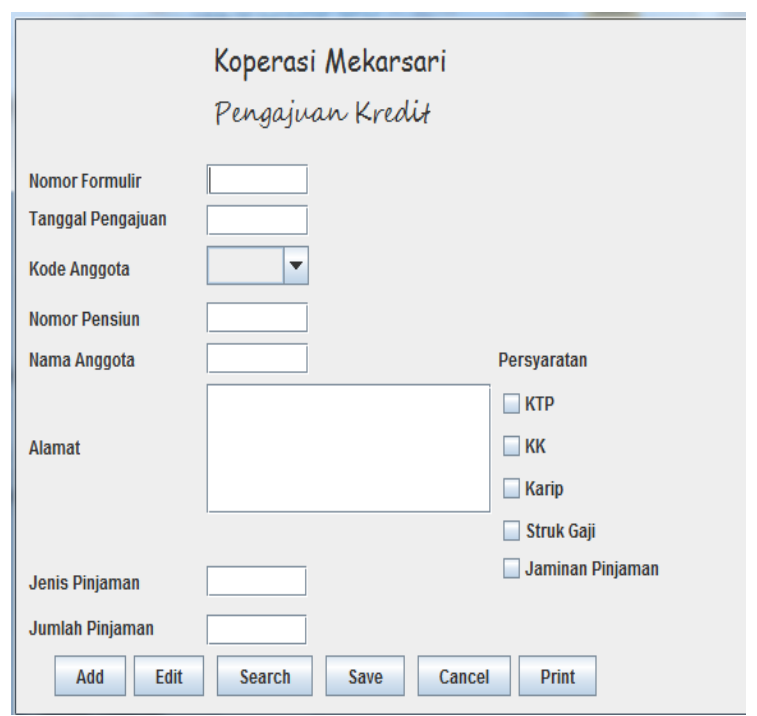

Gambar 9 User Interface Pengajuan Kredit

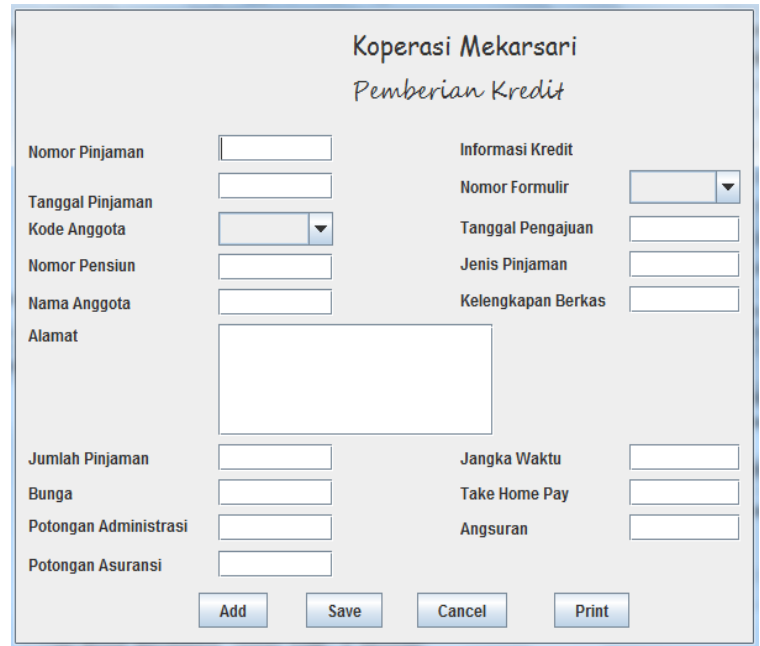

Gambar 10 User Interface Pemberian Kredit

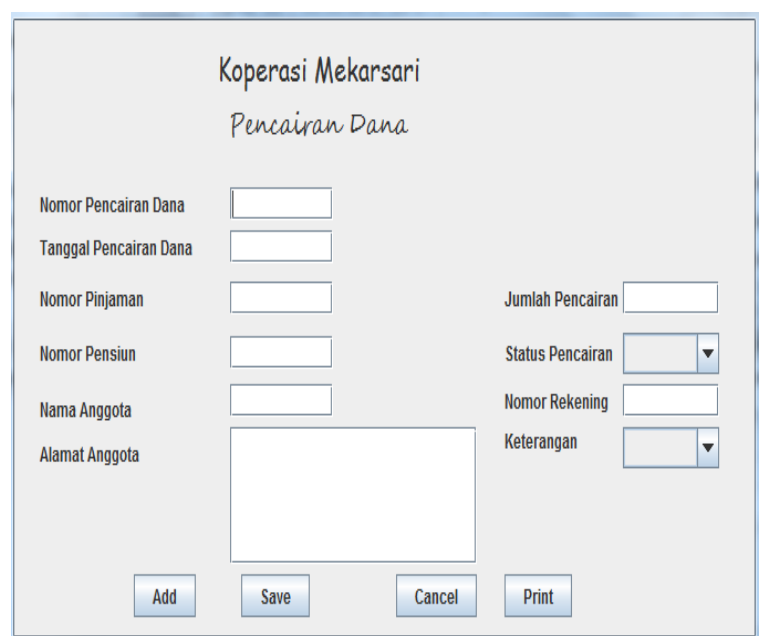

Gambar 11 User Interface Pencairan Dana

Setelah user interface dirancang dan sudah ditentukan juga databasenya, maka program siap untuk dibuat. Dalam artikel ini, penulis menggunakan pemrograman Java dengan MySql sebagai databasenya. Berikut contoh beberapa penggalan program Login dengan menggunakan Java:

import javax.swing. *;

import java.awt. *;

import java.awt.event. *;

public class loginDialog extends JFrame

\{

JLabel label $=$ new Jlabel();

private JButton tombol_login = new JButton(); private JTextField idUser $=$ new JTextField(); private JPassword password = new JPasswordField();

private JLabel jLabel1 = new JLabel(); private JLabel jLabel 2 new JLabel();

JPanel panel = new JPanel();

private JButton tombol_OK= new JButton();

JDialog dialog = new JDialog(); /** 
Paradigma - Jurnal Informatika dan Komputer, 2September2019

P-ISSN 1410-5063, E-ISSN: 2579-3500

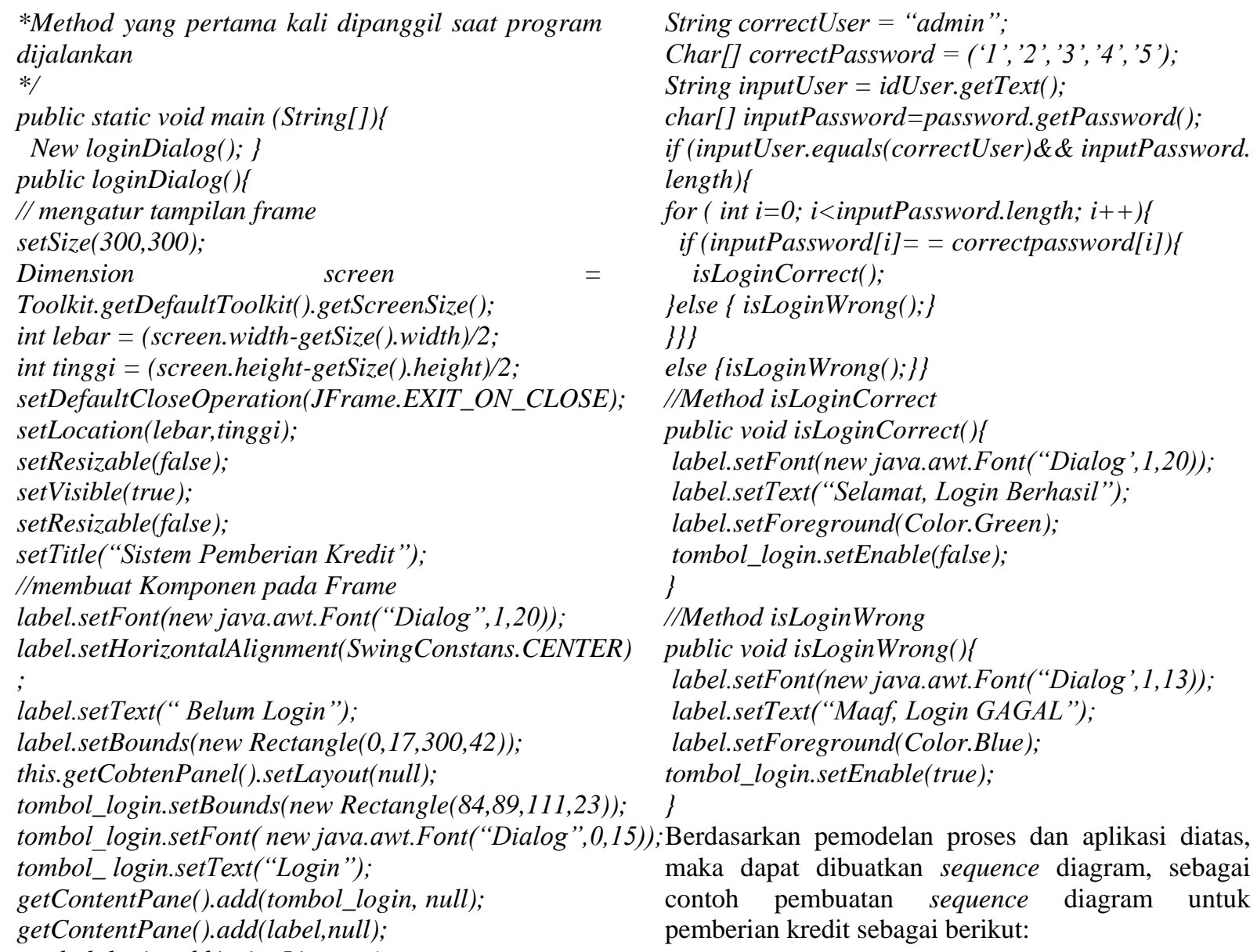

tombol_login.addActionListener( new java.awt.event.ActionListener()\{ public void actionPerformed(ActionEvent e)\{ kotakDialog(); j

));

kotakDialog(); \}

//Method kotakDialog public void kotakDialog()\{

idUser.setText(" “);

idUser.setBounds(new Rectangle(88, 5, 150,20));

password.setText(“ " );

password. setBounds(new Rectangle(88, 5, 150,20));

jLabel1.setHorizontalAlignment(Swing Constants.RIGHT); jLabel1.setText("Nama User : ");

jLabell. setBounds(new Rectangle $(0,5,80,26))$;

jLabel2. setHorizontalAlignment(Swing Constants.RIGHT); jLabel2.setText("Password: ")”;

jLabel2.setBounds(new Rectangle(0,30,80,22));

tombol_OK.setText("Login");

tombol_OK.setBounds(new Rectangle(88, 60, 60,20)); tombol_OK.addActionListener(

java.awt.event.ActionListener()\{

public void actionPerformed(Actionevent e)\{ checkLogin();

\}

));

// Method checkLogin public void checkLogin()\{

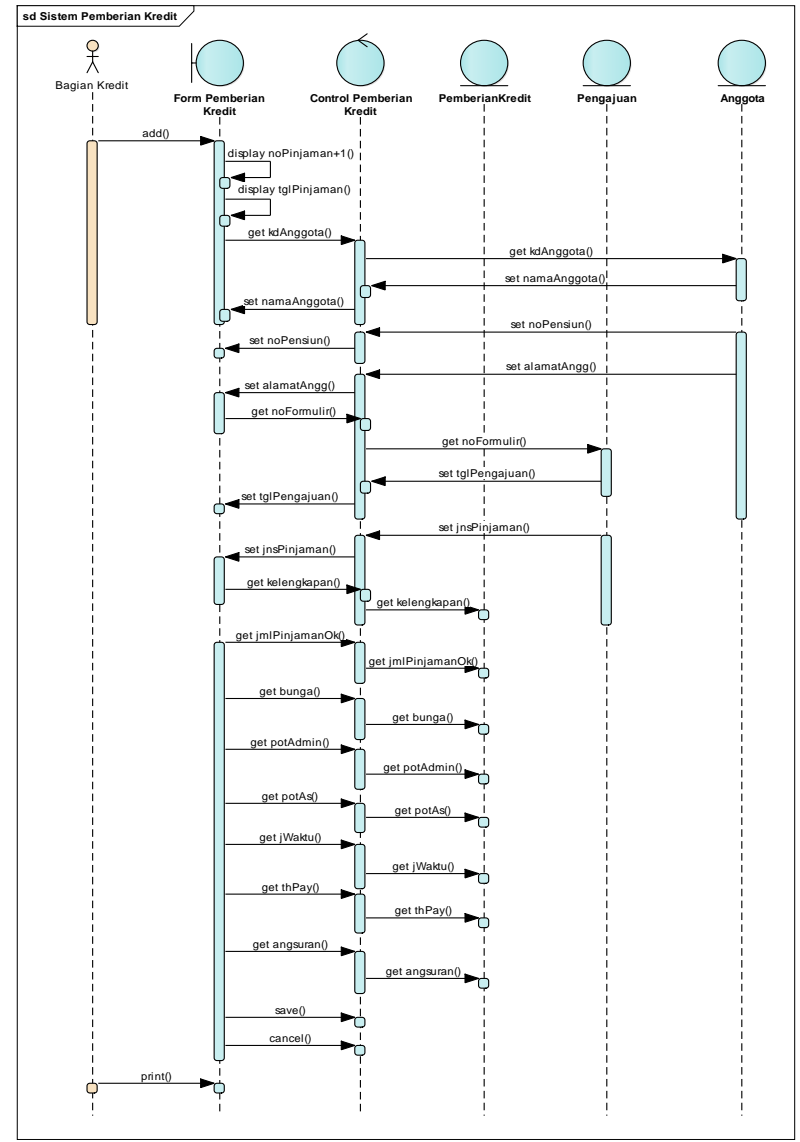

Gambar 12 Sequence Diagram 


\section{Pengujian dan Pergantian}

Tahap pengujian dilakukan setelah tahap pemodelan aplikasi selesai dilaksanakan. Ini berarti aplikasi program penerimaan kredit nya sudah selesai. Sehingga diperlukan adanya pengujian terhadap aplikasi program tersebut. Pengujian ini sangat diperlukan, karena sebagai pemeriksaan terhadap aplikasi programnya, apakah sudah sesuai dengan yang diinginkan pemakai atau belum, apakah masih terjadi kesalahan atau error dalam programnya, apakah kebutuhan input dan output sudah sesuai dengan tahapan awalnya. Pengujian ini dilakukan dengan menggunakan data operasional yang dimilliki oleh Koperasi Mekarsari, sehingga hasil yang ditampilkan dalam program tersebut, bisa di cek apakah sudah sesuai atau belum. Disamping itu, langkah pengujian ini dilakukan dari dua sisi, yaitu dari sisi pengembang dan dari sisi pengguna akhir. Sehingga dapat disimpulkan bahwa dengan melalui tahap pengujian ini, dapat diketahui sejauh mana sistem informasi yang diimplementasikan tersebut memiliki nilai (manfaat) bagi pengguna didalam menyelesaikan masalah yang ada serta bagaimana penilaian pengguna terhadap layanan yang diberikan, seperti tingkat kepuasannya (Pratama, 2014).

Critical Success Factor (CSF) dapat juga digunakan sebagai sarana untuk melakukan pengujian. CSF merupakan kumpulan analisa yang terdiri dari banyak proses sebagai penentu keberhasilan. Biasanya CSF digunakan untuk mencapai misi dari oragnaisasi atau perusahaan. Sedangkan tujuan dari penggunaan CSF itu sendiri adalah untuk dapat membantu dalam menentukan kegiatan apa yang harus dilakukan terlebih dahulu dan menetukan informasi seperti apa yang dibutuhkan (Hayati, 2018).

\section{KESIMPULAN}

Berdasarkan penjelasan diatas, maka dapat ditarik kesimpulan sebagai berikut:

1. Koperasi meupakan kumpulan orang atau badan usaha yang berlandaskan asas kekeluargaan, dan berdasarkan pada Pancasila dan UndangUndang 1945. Perkembangan Koperasi di Indonesia sendiri sangat pesat kemajuannya. Koperasi menjadi salah satu pilar dalam membantu roda perekonomian di Indonesia. Karena Koperasi merupakan usaha yang pro rakyat, untuk kalangan menengah ke bawah. Oleh karena itu, dengan perkembangan Koperasi ini haruslah didukung dengan penggunaan teknologi yang baik pula. Sehingga Koperasi membutuhkan adanya sistem informasi yang baik, yang dapat membantu dalam mengelola data-datanya.

2. Koperasi Mekarsari, merupakan salah satu jenis Koperasi Simpan Pinjam, yang perkembangannya sangat pesat. Salah satu layana yang diberikan oleh Koperasi ini memberikan kredit atau pinjaman kepada anggotanya. Namun dalam pelaksanaan sistemnya, ternyata sistem pemberian kreditnya masih dilakukan secara konvensional, sehingga hal ini menimbulkan beberapa permasalahan, seperti : pemberian kredit kepada para anggota masih dicatat secara tulis tangan di buku pinjaman; penyimpanan dokumen yang kurang rapi sehingga mengakibatkan dokumen sering tercecer dan hilang; serta tidak adanya pembatasan ruang kerja. Permasalahan ini tentunya sangat menganggu kinerja dari sistem pemberian kreditnya. Oleh karena itu Koperasi mekarsari membutuhkan adanya sistem yang baru, sistem yang terkomputerisasi untuk membantu menyelesaikan permasalahannya.

3. Pembangunan sistem baru yang dilengkapi pembuatan aplikasi program pada Koperasi Mekarsari ini tentunya memberikan banyak manfaat yang diperoleh, seperti kemudahan dalam memberikan pelayanan kepada anggota, pencarian data dapat dilakukan secara cepat, penyimpanan data menjadi rapid an terstruktur serta pembuatan laporan pemberian kreditnya menjadi cepat dan tepat waktu serta data-data yang ditampilkan dapat dipertanggungjwabkan kebenarannya. Dan untuk membantu pembangunan sistem pemberian kredit tersebut menggunakan metode rapid application development. Sehingga tujuan utama dari pembangunan sistem pemberian kredit pada Koperasi Mekarsari ini tercapai.

\section{REFERENSI}

Akil, I. (2018). Referensi Dan Panduan UML 2.4. Jakarta: Ibnu Akil. Retrieved from www.nulisbuku.com

Anggoro, D., Umar, M. D., Vinanty, E., \& Dananjaya, D. (2015). Rancangan Sistem Informasi Koperasi Simpan Pinjam Guru Dan Pegawai. Seminar Nasional Teknologi Informasi Dan Komunikasi, 2015(Sentika), 213-222. Retrieved from https://fti.uajy.ac.id/sentika/publikasi/makalah/ 2015/28.pdf

Fuad, M. (2016). Perancangan Sistem Informasi Simpan Pinjam Pada Koperasi "Kopitama" Depok, 9(5), 3-7. Retrieved from https://ejournal.gunadarma.ac.id/index.php/ugj 
Paradigma - Jurnal Informatika dan Komputer, 2September2019

P-ISSN 1410-5063, E-ISSN: 2579-3500

ournal/article/view/1460/1242

Hayati, N. (2018). Analisis Bisnis Internal Dengan Metode Critical Success Factors (Csf) Dan Value Chain (Studi Kasus Pt. Farmasi X). MIND Journal, $1(1), \quad 36$. https://doi.org/10.26760/mindjournal.v1i1.36

Hidayati, N. (2018). Implementasi Metode Rapid Application Development Dalam Pembangunan Sistem Penerimaan Kas Atas Penjualan. Paradigma, $\quad X X(1), \quad 39-47$. https://doi.org/DOI: 10.31294/p.v20i2

Nazir, M. (2014). Metode Penelitian. Bogor: Ghalia Indonesia.

Nugroho, A. (2017). Pemrograman Berorientasi Objek Menggunakan C++. Yogyakarta: Andi Offset.

Pratama, I. P. A. E. (2014). Sistem Informasi dan Implementasinya. Bandung: Informatika.

Setiawan, C., \& Rinawati. (2015). IMPLEMENTASI APLIKASI PEMINJAMAN DAN PEMBAYARAN ANGSURAN PADA BPR KABUPATEN BANDUNG, 9(1), 37-47. Retrieved from http://www.jurnal.stmikmi.ac.id/index.php/jcb/article/viewFile/125/149

Sugiarti, Y. (2018). Dasar-Dasar Pemrograman Java Netbeans Database, UML dan Interface. Bandung: PT. Remaja Roskadarya.

Sukamto, A. R., \& Shalahuddin, M. (2018a). Rekayasa Perangkat Lunak Terstruktur dan Berorientasi Objek. Bandung: Informatika.

Sukamto, A. R., \& Shalahuddin, M. (2018b). Rekayasa Perangkat Lunak Terstruktur Dan Berorientasi Objek (Revisi). Bandung: Informatika.
Syafriansyah, M. (2015). Analisis sistem dan prosedur pemberian kredit pada koperasi simpan pinjam sentosa di samarinda. Ilmu Administrasi Bisnis, 3(1), 83-93. Retrieved from http://ejournal.adbisnis.fisipunmul.ac.id/site/wpcontent/uploads/2015/02/Journal M.Syafriansyah pdf (02-25-15-08-19-18).pdf

Tofik Isa, I. G., \& Hartawan, G. P. (2017). Perancangan Aplikasi Koperasi Simpan Pinjam Berbasis Web. Ilmiah Ekonomi Vol. 5 Edisi 10, 5, 139-151. Retrieved from http://eprints.ummi.ac.id/60/3/Perancangan Aplikasi Koperasi Simpan Pinjam Berbasis Web \%28Studi Kasus Koperasi Mitra Setia\%29.pdf

Tohari, H. (2014). Analisis serta Perancangan Sistem Informasi melalui Pendekatan UML. Yogyakarta: Andi Offset.

\section{PROFIL PENULIS}

Nur Hidayati, lulusan S1 dari Universitas Abadi Karya Indonesia Semarang dan S2 dari STMIK Nusa Mandiri Jakarta. Dosen tetap di Universitas Bina Sarana Informatika Fakultas Teknologi Informasi untuk Program Studi Sistem Informasi, yang mulai bergabung pada tahun 2003, dan melakukan aktivitas mengajar di Universitas Bina Sarana Informatika Kampus Kota Bogor.

Ety Nurhayaty, lulusan S1 dari STIE Manajemen Bisnis Bandung dan S2 dari Universitas Bina Sarana Informatika Bandung. Dosen tetap di Universitas Bina Sarana Informatika Fakultas Teknologi Informasi untuk Program Studi Sistem Informasi Akuntansi, yang mulai bergabung pada tahun 2009, dan melakukan aktivitas mengajar di Universitas Bina Sarana Informatika Kampus KotaBogor. 